\title{
Just(ice) Do It! Re-membering the Past through Co-affective Aesthetic Encounters with Art/ History
}

\section{Nike Romano}

\begin{abstract}
The article explores the possibilities of reconfiguring an Extended Curriculum Programme's history of art and design curriculum in a South African university of technology and examines whether critical arts-based pedagogical encounters can affect students and my own becoming. To this end, the paper describes and analyzes an art history pedagogical encounter that explores ways in which educators and students might respond to calls to decolonise the academy and work affirmatively with difference(s) both within classroom encounters and society at large. The paper draws on the work of Donna Haraway, Karen Barad and Bracha Ettinger, three feminist theorists who move beyond binary 'othering' and explore notions of both/and conceptions of difference(s) and share a common understanding of subjectivity as partial, co-affecting and coemerging. The entanglement between the afore mentioned theories brings together posthuman(ist) theories of diffraction and Ettinger's human(ist) matrixial theory that emerges out of her psychoanalytic and aesthetic practices. Rather than position them as incompatible, it is my hope that by reading them through each other, new possibilities for shifting the binaries between, to quote Thiele (2014: 203), 'what supposedly counts as posthumanism and humanism respectively' may emerge.
\end{abstract}

Keywords: Critical arts-based pedagogies, decolonisation, posthumanism, matrixial theory, feminist new materialism, hauntology 
Raising questions of history, memory, and politics (all of which are rooted in and invested in particular conceptions of time and being) ... [are] ... about the possibilities of justiceto-come, the tracing of entanglements of violent histories of colonialism (with its practices of erasure and avoidance as an integral part of an embodied practice of re-membering which is not about going back to what was, but rather about the material reconfiguring of spacetimemattering in ways that attempt to do justice to account for the devastation wrought as well as to produce openings, new possible histories by which time-beings might find ways to endure (Karen Barad 2018:62).

\section{Introduction}

In the context of ongoing contestations within institutions of higher education in South Africa, this article describes and analyzes an art history pedagogical encounter that sought to find ways in which educators and students might respond to calls to decolonise the academy and work affirmatively with difference(s) both within classroom encounters and society at large. Located in the Design Extended Curriculum Programme (ECP) Foundation course of the Cape Peninsula University of Technology (CPUT), the research explores the possibilities of reconfiguring a history of art and design curriculum in a South African university of technology and examines whether critical arts-based pedagogical encounters can affect students and my own becoming.

The aim of CPUT's ECP is to increase the throughput rate of at risk students who, due to their secondary education backgrounds, may not be adequately prepared for higher education/university study. Following the guidelines for the implementation of ECPs at CPUT, the enquiry adopts multifaceted pedagogical approaches that seek to provide students with 'extensive pedagogic curricula and psycho-social support in order to support students' transition to university learning and preparing them for the mainstream programmes that they will join the following year'.

Ndlovu-Gatsheni (2016) notes that South Africa continues to be 'haunted by the struggle for inclusion and equality by those who have been 
excluded, peripheralised and pauperised since the time of colonial encounters'. These hauntings are imbrocated in CPUT, an institution that is traumatised on many levels. For example, following the 2001 National Plan for Higher Education, CPUT was grafted from the merger between two Technikons that had been conceived within the violent history and logic of apartheid South Africa (see Gachago et al. 2015 for the effects of merging). Furthermore, the campus is built on the ruins of District $\mathrm{Six}^{1}$, a vibrant mixed-race community that was annihilated after the land was declared a whites-only area under the Group Areas Act of 1950. More recently, student protests that highlight the ongoing struggles that students face on a daily basis continue to haunt the troubled institution by challenging ongoing epistemological domination and cognitive injustice, and demanding quality, relevant and fee free higher education (Ndlovu-Gatsheni 2016). It is within these interconnected layers of trauma and troubling times that I explore how teachers and learners might cocreate socially just pedagogies through pedagogical encounters that foreground the need to acknowledge, respect and work affirmatively with differences so as to create spaces in which transformation can occur.

Given the complexity of the above mentioned histories, the paper will argue that affective encounters with art history can offer possibilities for students' and my own becoming, within the university. In particular it will foreground the need for both lecturers and students to deal with the ongoing traumas associated with historical apartheid injustices that affect our lives, as well as site-specific traumas that arose out of student protest action that resulted in the early closure of our campus in 2017. In this regard, the research outlines a pedagogical strategy that activates possibilities for participants (both students and myself) to grapple with our asymmetrical and ambivalent past/presents in order to surface, access and bear witness to the trauma of each other in ways that are neither engulfing nor assimilating ${ }^{2}$. This is important because it not only foregrounds the crucial role that relational pedagogies play

${ }^{1}$ District Six was a municipal district of Cape Town that was home to a mixed community of freed slaves, merchants, artisans, labourers and immigrants. In 1966 it was declared a white area under the Group Areas Act of 1950. More than 60000 people were forcibly removed to outlying areas of Cape Town, their houses were flattened by bulldozers.

2 In this context, trauma is therefore understood as grounded in an ethics of solidarity, compassion, and encounter. 
in challenging traditional hierarchies between lecturer/learner, but also offers the possibilities for building trust and solidarity during classroom encounters.

Given the precarious state of the university after months of ongoing student protest action the previous year, the lesson sought to work with epistemological imperatives that would have ongoing ethico-ontological effects on students as they embarked on their university careers. At the same time it foregrounded some of the complexities and ambivalences associated with the teaching and learning of art history, a discipline that is both founded on and embodies Eurocentric cultural hegemonic ideologies that are 'embedded in both theory and institutional and pedagogical practices' (Braidotti 2013:2).

With this in mind, as educator, the challenge was to find ways of both critically disrupting the pejorative western canon of art history without reinforcing it as normative, whilst positioning students as central rather than marginalised within the university. To this end, critical posthumanism/ feminist new materialism and critical arts-based pedagogies provide the theoretical lenses through which an understanding of how students' lived experience is both central to and productive of new knowledges.

To begin, I summarise key debates about decolonisation of the university. I then locate the research within a critical posthumanism/ feminist new materialism theoretical framework. This is followed by the case study and pedagogical findings that continue to inform my practice. Strands of students' writings as well as excerpts of my own reflexive journalling are interwoven through this text as we research-create ${ }^{3}$ (Manning 2016) and render each other capable throughout relational encounters with art/ history (Harraway 2016).

\section{Summary of Decolonisation Debates}

The Council of Higher Education's November 2017 issue of Briefly Speaking, arranges the debates around decolonisation into four themes that I summarise in what follows. The first deals with what content is taught, and calls for content that is 'relevant, effective and empowering for the people of Africa

3 Manning argues that the term research-creation opens up the differential between making and thinking and offers a 'fertile field for thinking this coming-into-relation of difference' (Manning 2016:11). 
and, more particularly, for the immediate African societies the universities serve' (Nkoane 2006:49).

Premised on an understanding of academic literacies as socially constructed, the second theme focuses on the transformation of how content is taught. Arguing that academic literacies are not a value-neutral set of skills (Boughey \& McKenna 2016), it becomes critical that educators do not assume prior knowledge as this can result in students feeling alienated and pressurised to assimilate into the 'dominant meanings, norms, codes, practices and values of academia' (Briefly Speaking 2017:5). It is imperative therefore, that in order to decolonise, students become co-constructors of a curriculum that is reconfigured as 'a co-constructed set of understandings rather than a static object that students passively receive' (2017:5). Considering the above imperatives, finding ways of working with art/history so as not to render those students whose indigenous knowledges and histories have traditionally been excluded to experience feelings of deficit due to lack of cultural capital (Bourdieu 1979) becomes key.

Concerned with the Cartesian dualist structure of the academic project, the third theme focuses on foregrounding of 'subjugated knowledges' and troubling of the split between epistemology and ontology that privileges knowledges based on western rationalism over indigenous knowledges (Ndlovu-Gatsheni 2014). Following on from this, the fourth theme attends to how social and power relations are practiced in pedagogical encounters, as well as between the researcher and those being researched. For the purposes of this article, the above-mentioned themes are read through one another because they are differentially entangled and all have impact on and are implicated in this study.

\section{Theoretical Framework}

Working in the field of visual art/design, I am drawn to theoretical frameworks that theorise the process of diffraction as a way of seeing and understanding the world differently. In this regard, I turn to feminist new materialism/critical posthumanism theories that trouble binary logics that separate teacher/student and researcher/researched and reconceptualise them as co-creative, becomingwith and co-response(a)ble (Bozalek \& Zembylas 2016). Bozalek \& Zembylas (2016) also argue that they challenge neoliberal society's privileging of binary thinking that valorises the human over the non-human, the individual over the 
collective and the discursive over the material world. Accordingly, rather than limit understanding to a representationalist view of words and things, emphasis is placed on relationships and importantly, on finding commonalities (rather than differences) in human and non-human entanglements.

I refer to Donna Haraway (1988; 2000; 2016), Karen Barad (2007; 2010; 2014; 2017; 2018) and Bracha Ettinger (2005a; 2005b; 2006), three feminist theorists who move beyond binary 'othering' and explore notions of both/and conceptions of difference(s) and share a common understanding of subjectivity as partial and co-affecting. Following Thiele's (2014) inquiry into 'an ethos of diffraction as primary relating-in-difference', the entanglement between the aforementioned theories bring together posthuman(ist) theories of diffraction and Ettinger's human(ist) matrixial theory that emerges out of her psychoanalytic and aesthetic practices. Rather than position them as incompatible, it is my hope that in reading them through each other, new possibilities for shifting the binaries between, to quote Thiele (2014: 203), 'what supposedly counts as posthumanism and humanism respectively' may emerge 4 . I elaborate on these theorists in turn.

Haraway's seminal work on situated knowledges (1988) critiques Western Enlightenment notions of universal knowledge as value-free because it positions students as situated generators of knowledge in their own right and thereby challenges unequal power relations embedded in traditional pedagogy and curricula. Of relevance too, are her more recent writings on 'staying with the trouble' (2016) whereby she advocates working affirmatively with ambiguous and damaged pasts in order to build more sustainable futures. By urging us to 'make trouble ... [and] ... stir up potent response[s] to devastating events ... [and] ... settle troubled waters and rebuild quiet places' (2016:1), Haraway proposes response-ability as an ethical way of being in the world and argues that rather than 'clearing away the present and the past in order to make futures for coming generations', we render each other capable through our ongoing relations in the thickening present (2016:1).

Exploring optics in science studies, Haraway moves beyond notions of reflectivity and reflexivity that 'displace the same elsewhere', and turns to the

4 Thiele's proposition is helpful in the South African context where an ongoing critique of posthumanism is that it ignores the structural needs of those presently disempowered, and that it assumes that all people are treated equally as humans. 
'process of diffraction as an optical metaphor for another kind of critical consciousness ... [that is] ... committed to making a difference' (2000:102) (e.a.). Significantly, the process of diffraction maps both the process and where the effects of difference appear and, as Haraway explains, makes visible 'all those things that have been lost in an object; not in order to make the other meanings disappear, but rather to make it impossible for the bottom line to be one single statement' (Haraway 2000:105) .

Building on Haraway's (2000) recognition of the possibilities that diffraction offers the understanding of difference and of making a difference that matters, Barad's posthumanist theory of agential realism, that is generated out of 'a diffractive reading of quantum physics through contemporary issues of social justice', reveals difference/s as ongoing and non-binary (2018:G110). In/formed by physicist Niels' Bohr's diffraction experiments that show how the process of diffraction, as a methodological apparatus, implicates humans in the production of knowledge, Barad coins the term 'ethico-ontoepistemological' thus drawing attention to how ethics, ontology and epistemology are mutually constituted. The shift towards an ethico-ontoepistemological understanding of knowledge production de-centres the dominant representational role that language plays in positioning humans as separate from the world and foregrounds performativity that shifts the focus from 'descriptions of reality ... to matters of practices/doings/actions' (Barad 2003:802). This approach 'allows matter its due as an active participant in the world's becoming ... and it provides an understanding of how discursive practices matter' (Barad 2007:136). By highlighting the relationship between ontology, materiality and agency, Baradian ethics reveals the crucial role that response(a)bility and accountability play in the lively relationalities of becoming of which we are a part (2007:393). This is usefeul within in the context of higher education because it offers ethical possibilities and responsibilities for teachers and students in shaping the future for humans, nonhumans and the material environment in the production of knowledge (Dolphijn \& van der Tuin 2012:69).

5 Haraway elaborates 'diffraction does not produce 'the same' displaced, as reflection and refraction do. Diffraction is a mapping of interference, not of replication, reflection, or reproduction. A diffraction pattern does not map where differences appear, but rather maps where the effects of difference appear' (Haraway 2000:101). 
A quantum understanding of diffraction troubles Newtonian understandings of the universality and homogeneity of space, time, and matter, and also undoes the idea of dichotomy itself (Barad 2017: G110). Accordingly, Barad develops the notion of the agential cut that - rather than split entities into two separate parts - cuts 'together-apart' as a 'material act that is not about radical separation, but on the contrary, about making connections and commitments' (Barad: 184). Barad writes 'there is no singular act of absolute differentiation, fracturing this from that, now from then' (2014:168). Instead differences shift within "every "thing", reworking and being reworked through reiterative reconfigurings of spacetimematterings ${ }^{6}[\ldots]$ each being (re)threaded through the other' (2017:178 - 179). Barad's insights are significant for the teaching and learning of art history because they reveal how the present is full of ongoing intra-actions ${ }^{7}$ that continue to be in/formed by 'ghostly causalities' that trouble time. Drawing on Derrida's (1994) notion of hauntology, she writes 'Hauntings are not immaterial, and they are not mere recollections or reverberations of what was. Hauntings are an integral part of existing material conditions' (2018: 74). It is to these hauntologies from the past with/in the present/future, that the case study will turn.

Ettinger's theory of matrixial trans-subjectivity emerges out of a psychoanalytic and aesthetic register that also disrupts the linearity of Cartesian time. Working with arts-based practices, that she terms 'artworking', Ettinger explores trans-subjective aesthetic encounters that are generated within a matrixial time-space that 'links the time of too-early to the time of too-late and plants them in the world's time' (Ettinger 2001:710). Ettinger conceptualises matrixial aesthetic practice as a 'means to effect the passage to

6 Barad explains that the 'past' and the 'future' are iteratively reworked and enfolded through the iterative practices of spacetimemattering because space and time are phenomenal and are intra-actively produced in the making of phenomena. Therefore neither space nor time exist as determinate givens outside of phenomena (2007:315).

7 Barad's neologism 'intra-action' signifies the mutual constitution of entangled agencies. She writes, '(intra-action is) ... in contrast to the usual "interaction", which assumes that there are separate individual agencies that precede their interaction, the notion of intra-action recognizes that distinct agencies do not precede, but rather emerge through, their intra-action' (Barad 2007:33). 
a future that accepts the burden of sharing the trauma while processing and transforming it ... whereby we can be with and remember for the other through the artistic act and through an aesthetic encounter' (Ettinger in Pollock 2010: 830).

Ettinger's theorisation of art as a 'transport station of trauma' (2005b: 711) activates a space-time that not only looks backwards but also forwards, thus reinforcing her proposition that art 'has to do with primary meanings and imaginable futures for the humane' (Kaiser \& Thiele 2018: 105). Art in the matrixial functions as a relational postconceptual practice in which art's function moves beyond art as testimony (given by the witness), towards an aesthetic wit(h)nessing. In other words, art has the potential to activate a compassionate and co-affective rapport between the artist, artwork and viewer that offers healing possibilities of 'historical memory for the injured other ... that is simultaneously witness and wit(h)ness ${ }^{8}$ (Pollock:2012). Arguing that the artist/viewer 'can't not-share with an-other, she can't not witness the other' during matrixial aesthetic encounters, instead Ettinger writes, 'they become partialised, vulnerable and fragilised wit(h)ness to one another' (2005:704). Her construction of the neologism 'wit[h]nessing' expands the notion of witnessing - that sets people apart from and therefore reinforces othering - in order to accommodate a compassionate response-ability of 'being with' and 'bearing witness' to the trauma of the other. Unlike an engulfing merging-with the other, matrixial wit(h)nessing does not give way to assimilation (Ettinger $2009 ; 2005$ b). Pollock writes that the insertion of the letter (h) into the word witness embodies the notion of being beside the other in a gesture that does not risk the assimilation of the other and is therefore 'much more than mere ethical solidarity' (2010:831).

Matrixial theory offers helpful insights for pedagogical praxis in which co-response-ability becomes key to building trust and solidarity within the learning environment. Arguing that that there is no discrete separation between subject and object, Ettinger foregrounds the transconnectedness of matrixial trans-subjectivity that is incapable of not sharing (2009: 9). Importantly,

8 The artist who is working through the cross-inscribed traces and is worked through by virtual, phantasmatic or traumatic real strings practices her art - art that is an aesthetic-in-action - as a healing, healing that is an ethics-in-action. Such is the co-response-ability of artworking and of healing in copoiesis (Ettinger 2005:708). 
Ettinger cautions that while matrixial aesthetic encounters offer possibilities for healing, they are also potentially risky because they inhabit matrixial timespace in which individual boundaries are transgressed and call forward selfrelinquishment and fragilisation (2005:705). As lecturer, I recognise that while entering into open and compassionate co-response-ability with students as we wit(h)ness each other through co-poietic encounters requires risk, matrixial encounters offer the potential of transforming traumatic events into subjectivising potentiality. The role that research-creation plays in affectively responding to/within trauma-and-affect as generative, rather than pathological, supports the move away from the deficit model that has historically been central to DHET notions of foundation pedagogy (Leibowitz \& Bozalek 2015:11). It seeks instead, to move beyond 'disadvantaged' narratives about victimhood, or pain, that rely on a deficit model, and explore possibilities of research-creation that think-with and move-with students' productive and affective sites of resistance in order to 'open new critical spaces that can sustain the connection between bearing witness and political transformation' (Zembylas 2006: 324).

The following case study focuses on a diffractive intra-action in which Cartesian spatio-temporality is troubled by the entanglements of artworks from the 'here and now' with artworks from the 'there and then' (Barad 2010: 244)9. The intention is to find different ways of working with the past by re-presenting and troubling histories so as to make a difference that matters (Barad 2007).

\section{Case Study}

The case study describes and analyses the introductory lesson of the 2018 theory course that aims to familiarise students with the discipline of art and design history and introduce them to current debates around the role that art and design history performs in contemporary design practices. While the pedagogical aims included orienting students towards the kind of material the syllabus would cover, they also emphasised the importance of relationality and

9 Barad conceptualises diffraction as an iterative (re)configuring of patterns of differentiating-entangling in which there is no moving beyond the past and there is no absolute boundary between here-now and there-then. For her, there is nothing that is new and there is nothing that is not new. 
how students could expect the content to be 'taught' during the course of the year.

With this in mind, the broad strategy focused on threading student's subjectivities through these art/histories, in order to foreground their lived experience as central to their learning. At the same time, it aimed to highlight the valuable role that art/history can contribute to the re-presenting of troubled histories that continue to affect our lives on a daily basis. Following Haraway's understanding of diffraction as an apparatus for making visible invisible histories, it seemed fitting to begin with the academy as site of contestation because it impacts directly on students. As a methodology, the intra-active diffractive process generated debates across the spatial/temporal through students and my subjective lived experience.

Barad provides helpful strategies in dealing with our troubled times by troubling understandings of time itself. She does this in order to "undo pervasive conceptions of temporality that take progress as inevitable and the past as something that has passed and is no longer with us as is' (2018:57). These insights informed the conceptualisation of the lesson which referenced the pivotal moment when the statue of arch-colonialist Cecil John Rhodes was removed from the University of Cape Town's (UCT) campus ${ }^{10}$. Fisher argues that 'haunting happens when a place is stained by time, or when a particular place becomes the site for an encounter with broken time' (2013:19). For UCT students, this time had come. Protesting against the systemic violence of the predominantly colonial culture of whiteness within the academy that left them feeling pressurised to assimilate, for students the statue not only reinforced Eurocentric hegemonic ideologies and practices, but also served as a haunting reminder that even though South Africa's democracy began in 1994, transformation had not taken place throughout South African Higher Education.

The \#rhodesmustfall movement garnered a groundswell of popular support and in the aftermath of the removal of the statue, the \#feesmustfall campaign that called for fee free higher education for all and the insourcing of outsourced workers gathered momentum. What followed was two years of protest action at higher education institutions (HEIs) across the country. In 2017, CPUT's classes were interrupted from August and in September after

\footnotetext{
${ }^{10}$ After months of student protests led by the \#rhodesmustfall movement, the statue was removed on 15 April 2015.
} 
several arson attacks and violent protest action, the university closed prematurely for the year. The effects of the protests reinforced the precarious position of the institution which in turn affected those students who were beginning their studies in 2018. Many of them had applied for admission in 2018, but because of the four month closure, their applications were not processed timeously and they never knew, until the last minute, whether they would be able to begin their studies the following year. Due to the intensity of the protests and the damage to property, it was also unclear whether the university would be up and running and open in time for the 2018 academic year.

At the beginning of 2018, it felt important to reference these uncertainties in order to encourage beginner students to actively grapple with the complexities and contestations around South African higher education. At the same time, rather than limit the discussion to the fall of Rhodes, and risk paradoxically re-positioning him as central, I wanted to open up debates across the spatial/ temporal that could forge understandings of art/ history's performative function and in so doing, highlight the ethico-ontoepistemological implications that arise out of material-discursive practices. By adopting this strategy, I also hoped that our discussions would surface broader themes around social justice that we could re-turn to throughout the course of the year. My understanding of re-turning follows Barad's (2018) notion of returning that is more than simply revisiting broader themes in a linear way. Rather it is about looping back to themes and 're-turning and turning our attention to a multiplicity of entangled histories' (Barad 2018:69).

Mignolo argues that given the ubiquitous presence of Western Modern aesthetics, decolonial thinkers should start with the legacy of modern aesthetics and its Greek and Roman legacies in order to delink from them (GatzambdeFernández 2014: 201). To this end, the lesson was structured around the diffraction of the removal of the Rhodes monument through two additional artworks, the first is the ancient Greek sculpture entitled Winged Victory of Samothrace, also known as the Winged Nike (See Figure 1) and the second is artist Sethembile Msezane's performance entitled, Chapungu - the day Rhodes fell (See Figure 2) that took place as the statue of Rhodes was removed ${ }^{11}$.

${ }^{11}$ Unearthed on the island of Samothrace in 1863 by French consul Charles Champoiseau, the Winged Nike was sent to France where it remains in the Louvre Museum. 
Nike Romano

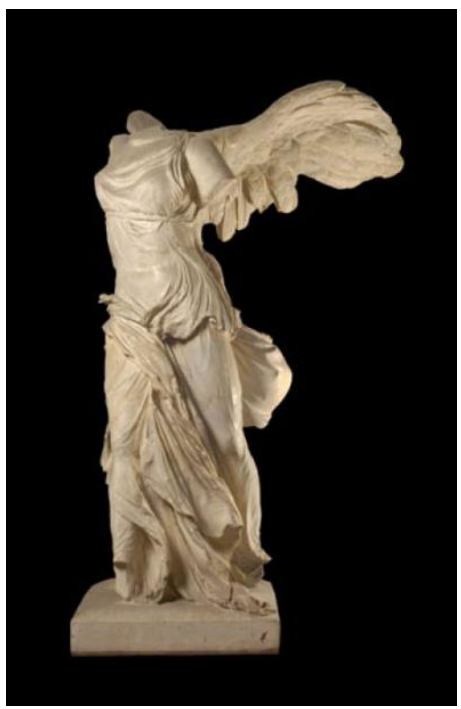

Figure 1 The Winged Goddess of Victory

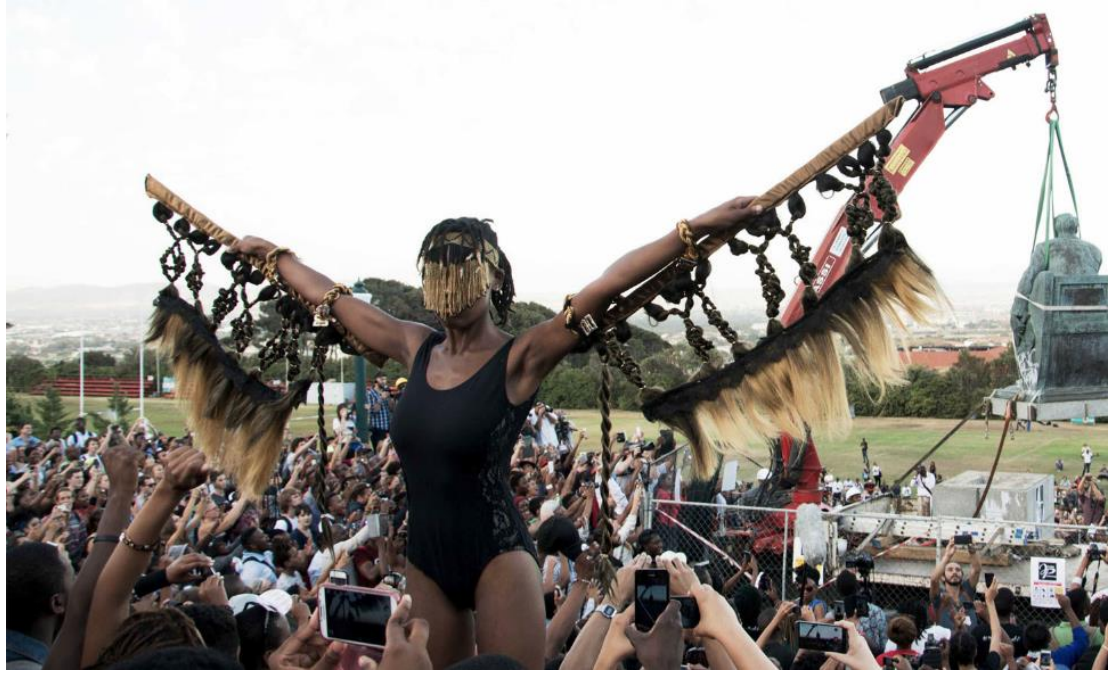

Figure 2 Sethembile Msezane performing Chapungu the day Rhodes Fell 
The pedagogical aim was to encourage students to engage with South Africa's colonial cultural legacy through and across time, in order to explore the relationship between art and power, as well as the transformative potential role that art plays in inspiring and building social justice. Moreover, following Garneau (2013) who argues that decolonial aesthetic activism should move beyond the mere revival of Indigenous cultural practices towards the need for 'Indigenous ways of knowing and being to reinvigorate and rebalance Western aesthetic practices, even to the point of de-Westernizing them', I was curious whether the diffractive encounter between an indigenous contemporary South African artwork and an ancient Hellenistic sculpture artwork might thicken an understanding of both artworks.

While Msezane's performance did not explicitly reference the Winged Nike, I was struck by the uncanny resemblance between the two artworks that embody such differing ideologies. I hoped that the patterns of difference generated through their intra-action would offer a useful introduction to the kinds of concerns that the course would be dealing with.

Msezane's performance references and challenges the unmitigated colonial practice of the pillaging of African artefacts, in this case one of the soapstone sculptures of the bateleur/short-tailed eagle, known as the Chapungu, that guarded the Great Zimbabwe settlement site that Cecil John Rhodes bought and housed in Groote Schuur, his residence in Cape Town ${ }^{12}$. According to Shona cosmology, the Chapungu is the divine messenger that intercedes between Mwari (the creator of human beings), the ancestral spirits and the living (Matenga 2011). The artists explains, 'The story of Chapungu and Rhodes in the same space and time asks important questions related to gender, power, self-representation, history making and repatriation... On that day, I embodied her existence using my body, while standing in the blazing sun for nearly four hours. Twenty-three years after apartheid, a new generation of radicals has arisen in South Africa .... From then on, I realized that my spiritual beliefs and dreams texture my material reality' (excerpt from TED talk). Shortly after the removal of the Rhodes statue, the Msezane visited Great

12 The remains are in the house, which was the official residence of eleven Prime Ministers of South Africa, in Cape Town, from 1911 - 1994, before the residence was moved to Westbrooke, under P.W. Botha. The latter was also taken up by Mr. Neslon Mandela, but renamed, as Genadendal, after the 1994 election. 
Zimbabwe and reperformed Chapungu as a symbolic act of returning the bird to its spiritual home (see Figure 3$)^{13}$.

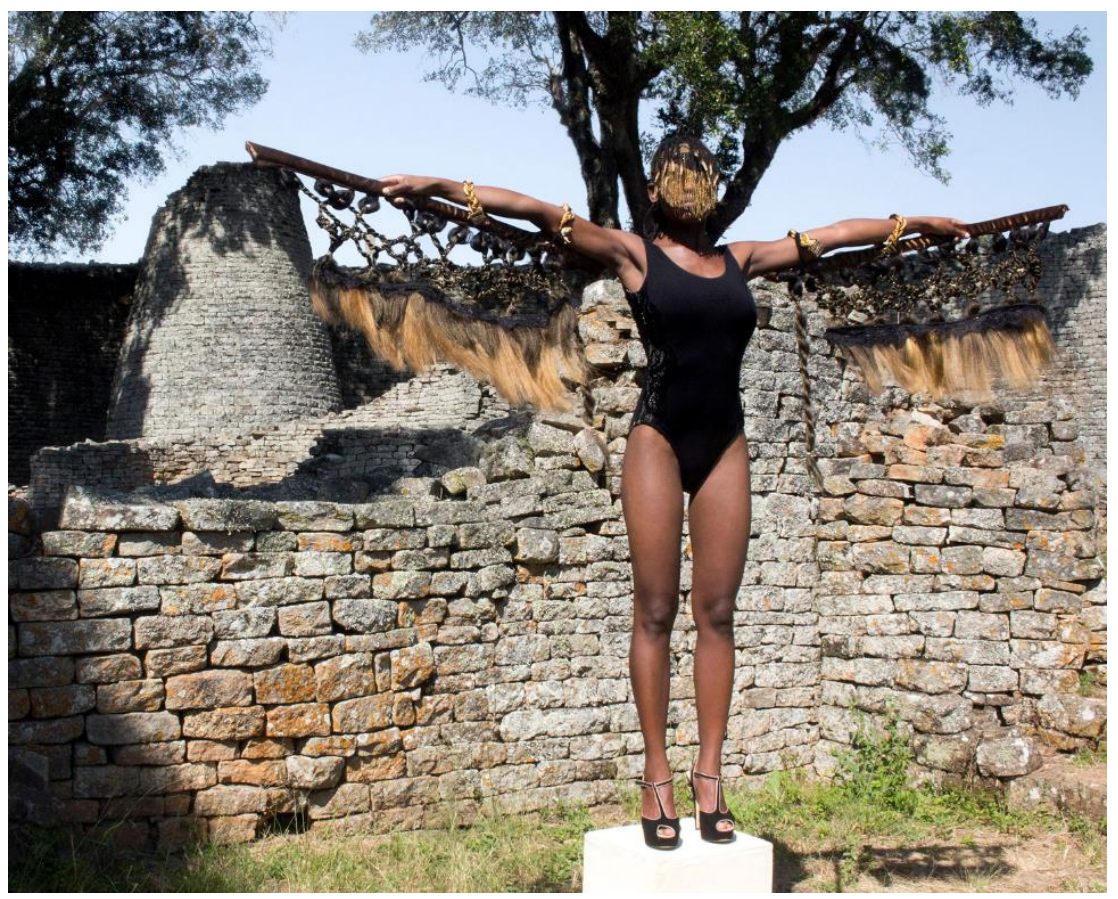

Figure 3 Sethembile Msezane, Chapungu - The Return to Great Zimbabwe, 2015.

Nike, the goddess of Victory was an attribute of Athena and Zeus. Her Roman equivalent was Victoria. With the advent of Renaissance Humanism and subsequent Enlightenment thinking, she has come to embody notions of victory, progress and reason - key tenets that underpin the colonial and imperialist projects that in/form South Africa's violent history. The overlays of this construct are felt in the haunting presence of the statues of Victoria,

13 See Msezane's TED talk in which she tells the story of Chapungu at https://en.tiny.ted.com/talks/sethembile_msezane_living_sculptures_that_stan d_for_history_s_truths 
Queen of the British Empire, that stand proudly outside the houses of parliament in Cape Town and in the Botanical Gardens in Durban. (See Figure 4 and Figure 5).

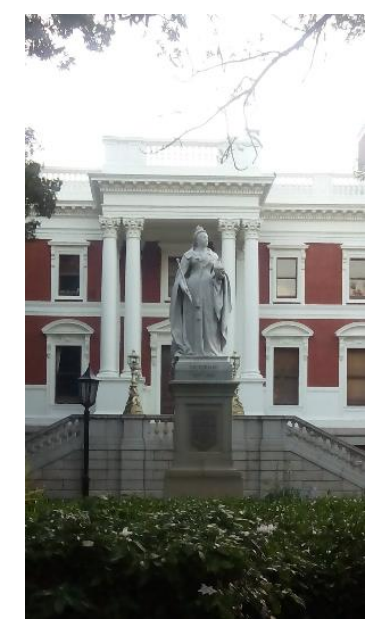

Figure 4 Queen Victoria, Houses of Parliament, Cape Town

Mindful of the sensitivity and complexity that the diffraction of the above mentioned artworks might generate necessitated an openness to risk and vulnerability on the part of participants, I was guided by Boler's (1999) writings on pedagogies of discomfort that provide a useful framework within which to explore the relationship between emotions and power. Boler urges educators to take collective responsibility in recognising how their economic and social positions are implicated in their teaching practices. Furthermore, her critique of 'passive empathy' alerts educators to the risk of both distancing the other 'whom we cannot directly help' whilst simultaneously distancing ourselves from recognising our own implication 'in the social forces that create the climate of obstacles the other must confront' (1999:158). In other words, in addition to teaching critical thinking, Boler calls on educators to take responsibility for their implicatedness in historic moments and highlights the need for students and educators to develop a nuanced ethical language that recognizes the ambiguity of ethical interrelations and acknowledges the 
complexity of working with/in difference during classroom encounters. In this regard, her proposal of 'collective witnessing' that is 'understood in relation to others, and in relation to personal and cultural histories and material conditions' (1999:178).

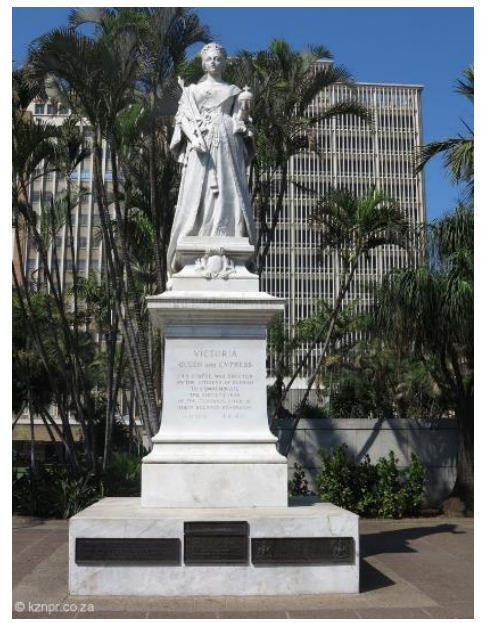

Figure 5 Queen Victoria, Botanical Gardens, Durban

Given the complex and ambiguous nature of the content, I understood, with some trepidation, that as educator I would have to 'wing it' because the encounter would be unpredictable. I drew on Roth's (2014) post-constructivist perspective of the 'living curriculum' and Seller's (2013) notion of the 'becoming curriculum' because they emphasise the need for ongoing, contingent response(a)bility and openness to indeterminant outcomes in pedagogical practice. I was curious to participate in an open-ended process that would reveal a multitude of patterns of difference that could trouble the flattening effects of dualistic thinking practices that reduce differences to either/or.

To begin students watched a short documentary about Msezane as well as video footage of her performance. Thereafter students were introduced to the Winged Nike. Working in small groups, students discussed the similarities 
and differences between the artworks. The intention was not one of juxtaposition that reinforces binary thinking, rather the aim was paradoxically to expose the limitations of binary logic as students begin to trace the patterns of difference that emerge from the diffractive overlays and in so doing, 'question the very notion a binary itself' (Barad 2014:174). Some examples of similarities included how both artworks reference the female body, have wings and were created to perform in public spaces. Students also noted differences such as time and context, one is human while the other is stone, the one embodies notions of victory and power, that the other seeks to overturn. However, it was the commonalities that the intra-action generated out that were significant to the teaching and learning encounter. After reporting back to the plenary, students were tasked with an in depth written assignment in which, rather than working with a given definition of decolonisation, they explored their subjective opinions and understandings of decolonisation and considered the transformative possibilities of artworks in bringing about social change.

Registered for a masters in fine art at UCT, Msezane describes how, on coming to Cape Town, she was struck by the proliferation of public sculptures commemorate South Africa's colonial and apartheid history throughout the city. She set about redressing the absence of the black female body in public space in a series of performances that insert the black female body in public space.

Walking down the street in the city that was now my home, I couldn't identify with the symbols and the figures that were supposed to represent a kind of national identity. These [monuments and statues] were white men ... They were colonial ... Dutch, Afrikaner nationalist men... I couldn't see anything African ... anything that was women ... anything that was like my mother and my aunts, or women that I knew. So for me, it was a task of reclaiming histories that had been omitted from public spaces ${ }^{14}$.

Msezane's words summarise the challenge of teaching relevant art/history in South Africa after centuries of systematic exclusion and absence on the one

${ }^{14}$ Extract taken from Matroos, J. 2018. Sethembile Msezane on why she uses her art as resistance, at: http://www.designindaba.com/articles/creativework/sethembile-msezane-why-she-uses-her-art-resistance 


\section{Nike Romano}

hand and the simultaneous inclusion and foregrounding of an art/history that promotes colonial ideology and hegemony on the other. With this 'double whammy' in mind, the assignment called on participants to engage with Southern Africa's colonial cultural legacy and the arbitrary creation of colonial borders, through and across time in order to understand how art functions as a symbol of power and, as in the case of Msezane's performance, how art offers the transformative potential to inspire and build social justice.

The simultaneous falling of Rhodes and the rising of Chapungu was a spectacle that was wit(h)nessed and documented by thousands of students. What follows is the artist's account of the event.

As the time came, the crane came alive. The people did, too shouting, screaming, clenching their fists and taking pictures of the moment on their phones and cameras. Chapungu's wings, along with the crane, rose to declare the fall of Cecil John Rhodes. Euphoria filled the air as he became absent from his base, while she remained still, very present, half an hour after his removal (Matroos 2018).

In terms of my own privileged subject position as a white, middle-class second generation South African/Greek woman, the haunting of the Winged Nike is also my own haunting because it is my namesake. Following Boler's proposal of 'testimonial reading' that encourages the educator to recognise herself as a 'battleground for forces raging...to which [she] must pay attention...to properly carry out [her] task', it was important to acknowledge the legacy of my subjectivity from day one $(1999: 167)^{15}$. 'Not in my name' is not an option as I recognise the repercussions of my cultural heritage that perpetuates systems of exclusion and exploitation. Similarly, encouraged by Haraway, I explore possibilities of working affirmatively with the complexities of situatedness, complicity and partial subjectivity in order to recuperate ambivalent losses and non-innocent pasts that continue to affect the present so that, 'like all offspring of colonizing and imperial histories, ... we relearn how to conjugate worlds with partial connections and not universals and particulars' (2016:20).

${ }^{15}$ Boler's (1999: 168) notion of testimonial reading calls for the analysis of the historical genealogy of emotional consciousness as part of the structure that forms and accounts for the other's testimony. 
Given students' familiarity with Nike as a global sports brand, the lesson also laid the foundations for deconstructing how notions of power and victory are inextricably linked to Ancient Greek culture's valorisation of the Olympic hero. Similarly, in looking backwards to the construction of the Victory ideal and by drawing attention to the ethical practices of the Nike brand with regards to the exploitation of child-labour in the manufacturing of their products, the encounter also provided an opportunity to engage the underlying cultural biases and imperatives that prop up global capitalism. In addition to making visible new connections of understanding the world and implicatedness in its ongoing worlding, the diffractive encounter also drew attention to our ongoing response(a)bility in working proactively in addressing issue of social justice. It seems fitting therefore to create the neologism Just(ice) do it, as a play on the Nike brand slogan, 'Just Do It!', in order to imagine a future of inclusivity and to understand difference as generative and affirmative. At the same time I question my privileged position as is evidenced in the following journal extract.

Can I question students' desire for globally branded goods, the Rolexes, the Adidas, the beats by Dre? Is it my place as a white woman of privilege to point out the inbuilt contradictions of global branding, the social and political implications of buying these products, the effect that they have on social relations, the environment, the reinforcing of the west as the leader of the world?

Concerned with mourning and justice, Barad asks what 'would make it possible to trace the practices of historical erasure and political a-void-ance, to hear the silent cries, the murmuring silence of the void in its materiality and potentiality?' (2018: 64) Her words resonate with an ongoing lament on the part of students who express their sense of loss of and desire for making visible their own histories that were systematically erased by colonial and apartheid hegemonic practices. As one student writes:

In Africa we have been taught that it is okay to undermine our very own intelligence ... We have been taught that the only way to be educated is through thinking like the colonists that occupied our country and exploited our economy. The people that came to our 
country and labeled our beliefs and culture as witchcraft, and they introduced us to their culture and made us undermine ours.

Unlike the Rhodes statue that looked eastwards towards the sunrise, Msezane turned her back on the statue and faced the university. By inserting herself between the statue and the University buildings, the artist simultaneously redressed the absence and erasure of indigenous histories brought about by colonialism and made visible the spectral possibility of an Afrocentric future.

Msezane is standing there in the crowd while other students remove the statue of the colonial man, she is not even facing the crowd, but what she does is lift her wings once she hears the crowd celebrating. This whole performance shows that Africans were never ready for the Colonial Government. They came while they all were not looking and the same way they came we [s] hall rise with our faces covered showing no individuality, but rising as Africans. Take control of our education, think like the Africans that we are, take back what the colonials stole from us: our culture, dignity and pride. As much as they have undermined us and dehumanized us we are rising above all those things and taking back all that has been stolen/taken.

Some students commented on the vulnerability of the Rhodes statue. As one student writes:

The Rhodes statue was powerless. If it had power, there wouldn't be much joy amongst the students of the University of Cape Town. Throughout that removal process, the statue was vulnerable because it was vandalised before the removal and during the protest.

The Winged Nike was also perceived in different ways. For one student it represented how 'Western culture has and still continues to dominate the world', whereas for another student, the artwork functions as 'success, triumph [and] superiority', a third student read the sculpture as a symbol of freedom.

Paradoxically, the intra-action of the two artworks was interpreted by one student as a powerful act of colonising the west. He wrote: 
Msezane's performance flipped that notion on its head ... by taking such a powerful symbol, highly esteemed highly European symbol and Africanizing it. In a sense colonializing it, very much like the Europeans did Africa. How ironic. Removing the symbol's old European identity and titling it as Chapungu-the day Rhodes fell.

What follows is a summary of the main pedagogical learnings that emerged from the lesson. To begin, the lesson confirmed the significance of working with artefacts that resonate with students' lives. Furthermore, because students could identify with the artist and her performance they understood the importance of symbols and their performative power, as well as their agency to affect change. Following on from this, the pedagogical exchange provided an opportunity for students to foreground their subjectivity in relation to the pressing debates around decoloniality within the academy. In other words, they understood through the material discursive encounter how we are all implicated in these performances for example:

Her bravery is an inspiration to many people around the country period she shows that women should also Stand Up For Themselves. She's powerful, Fearless, brave, strong physically and probably emotionally, spiritually... [She] shows the country of South Africa that the removal of the statue is a symbol that bit by bit South Africa is moving further apart from the British colony and being colonised.

The intra-action also revealed how iterations of the past continue to impact on the present/future as they constantly re-turned to the time of the Ancient Greeks, the time of Colonialism, the moment of the Chapungu rising. Similarly the notion of the future in the present was also evident as students discussed how Msezane's performance in the present would impact on their year ahead.

As a precursor to the year ahead, the lesson laid the foundations for various themes, that include redressing the effects of absence/presence, developing literacies around the representation of the female body, that we returned to throughout the year.

While the diffractive encounter encouraged students to address the concerns around decolonisation, it also afforded them an opportunity to make themselves visible as they position themselves within the academy. Similarly, the initial discussion paved the way for ongoing conversations that dealt 
specifically with understanding difference and beginning to build trust as we navigate asymmetrical differences ${ }^{16}$ both from the past and the present in the classroom.

With regards my own learnings, I am gaining a better understanding of the notion of response(a)bility, understood in this context as an ability to respond to students, that has become of increasing concern to my practice as educator.

\section{Conclusion}

As an introduction to the course, the lesson generated ethico-ontoepistemological effects for students and myself. The encounter also positioned students' knowledges as central to the course from the outset and helped to bridge the transition from community/school lives to their first year in the university. Similarly, by drawing on students' situated knowledges, concerns about epistemological access and the risk of assuming prior knowledge were addressed. Consequently, rather than feeling marginalised and pressurised to assimilate, students affirmed their own knowledges and understandings through their encounter with the artworks. Moreover, contrary to deficit discourses that tend to position first year students as unable to deal with complexity, the open-ended process encouraged students to grapple with layered and interconnected concepts without fear of getting them wrong. The pedagogical encounter also positioned the legacy of my heritage and surfaced the complexities of my implicatedness in the 'historic moment', an issue that continues to haunt and in/form my practice (Boler 1999). Finally, for some of us, the aesthetic encounter activated a matrixial rapport through which the relationship between ethics, epistemology and ontology were enacted as students and I engaged issues of decoloniality, social justice both within the academy and beyond.

The plinth of statue marks the site where the Rhodes statue stood on the UCT campus (See Figure 6). As a rhizomatic assemblage, it traces lines of flight that traverse the past, the present and the future. In addition to remembering the past, graffiti references the ongoing struggles around social and

16 These asymmetrical differences included between gender, race, class, religion, teacher, student etc. 
economic exclusion that defines many South Africans lived (Deleuze and Guattari 1980:9-10).

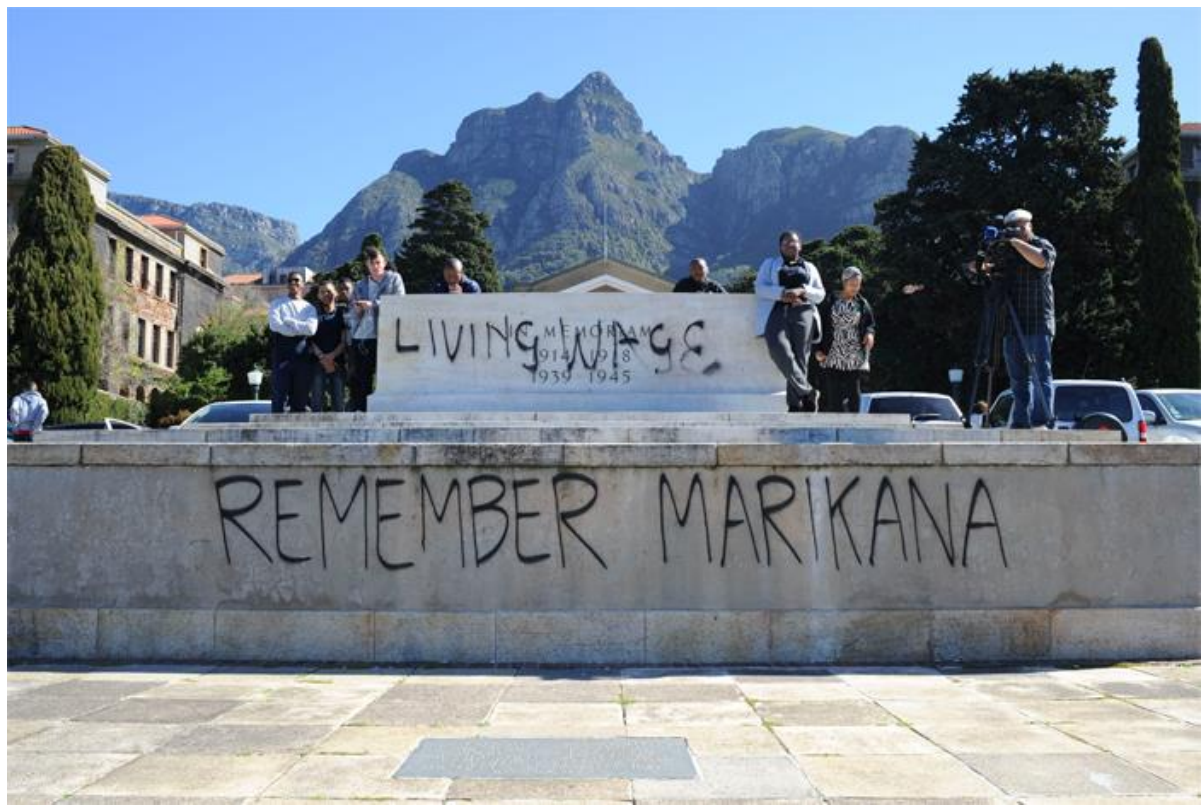

Figure 6: The remains of the Rhodes statue bearing an inscription of a poem by Rudyard Kipling that reads 'I dream my dream, by rock and heath and pine, Of Empire to the northward. Ay, one land From Lion's Head to Line!' and graffiti demanding a living wage and commemorating the 2012 Marikana Massacre when seventeen striking miners were massacred by South African Security forces.

\section{Acknowledgements}

Thanks to my supervisors Professors Vivienne Bozalek and Kathrin Thiele for their ongoing support, generosity and encouragement of my $\mathrm{PhD}$ project. I also thank Professor James Garraway for inviting me to the Montfleur writing retreat where much of this article was written. Thanks too, to the reviewers whose incisive and insightful comments enriched this article. Finally I thank the Design ECP students of 2018 who generously participated in this project and who taught me much more than I could ever teach them. 


\section{References}

Barad, K. 2007. Meeting the Universe Halfway: Quantum Physics and the Entanglement of Matter and Meaning. Durham, NC: Duke University Press. https://doi.org/10.1215/9780822388128

Barad, K. 2010. Quantum Entanglements and Hauntological Relations of Inheritance: Dis/continuities, SpaceTime Enfoldings, and Justice to come. Derrida Today 3,2: 240 - 268. https://doi.org/10.3366/drt.2010.0206 Barad, K. 2014. Diffracting Diffraction: Cutting Together Apart. Parallax 20,3: 168 - 187. https://doi.org/10.1080/13534645.2014.927623

Barad, K. 2017. No Small Matter. In Tsing, A., H. Swanson, E. Gan \& N.

Bubandt (eds.): Arts of Living on a Damaged Planet. Minneapolis: University of Minnesota Press.

Barad, K. 2018. Troubling Time/s and Ecologies of Nothingess: Re-turning,

Re-membering and Facing the Incalculable. New Formations 56 - 86.

https://doi.org/10.3898/NEWF:92.05.2017

Boler, M. 1999. Feeling Power: Emotions and Education. New York, NY: Routledge.

Boughey, C. \& S. McKenna. 2016. Academic Literacy and the

Decontextualized Learner. Critical Studies in Teaching and Learning (Cristal) 4,2: 1 - 9.

Bourdieu, P. 1979. Distinction: A Social Critique on the Judgement of Taste. London and New York: Routledge.

Bozalek, V. \& M. Zembylas. 2016. Critical Posthumanism, New Materialisms and the Affective Turn for Socially Just Pedagogies in Higher Education.

South African Journal of Higher Education SAJHE 30,3: 193 - 200.

Braidotti, R. 2013. Posthumanities. European Educational Research Journal 12,1: 1 - 19. https://doi.org/10.2304/eerj.2013.12.1.1

Deleuze, G. \& F. Guattari. 1987. A Thousand Plateaus: Capitalism and Schizophrenia. Massumi, B. (trans.). Minneapolis: University of Minnesota Press.

Dolphijn, R \& I. van der Tuin 2012. New Materialism: Interviews \& Cartographies. Open Humanities Press. https://doi.org/10.3998/ohp.11515701.0001.001

Derrida, J. 1994. Spectres of Marx: The State of the Debt, the Work of Mourning and the New International. Kamuf, P. (trans.). New York and London: Routledge.

Ettinger, B. 2000. Art as the Transport-Station of Trauma. In Ettinger, B.L. 
Artworking 1985 - 1999. Ghent: Ludion.

Ettinger, B. 2006. Matrixial Trans-subjectivity. Theory, Culture and Society 23,2 - 3: 218 - 222. https://doi.org/10.1177/026327640602300247

Ettinger, B. 2005a. Art, Memory, Resistance. iframework x ephemera 5,x: 690 -702 .

Ettinger, B. 2005b. Copoiesis. iframework x ephemera 5,x: 703 - 713.

Ettinger, B. 2009. Fragilisation and Resistance. Studies in The Maternal 1,2: www.mamsie.bbk.ac.uk

Fisher, M. 2015. What is Hauntology? Film Quarterly 66,1: 16 - 24. https://doi.org/10.1525/fq.2012.66.1.16

Gachago, D., Z. Sosibo, Ndeto \& E. Ivala 2015. Nostalgia, Anxiety and Gratification: Narratives of Female Staff in a Merged Higher Education Institution. Alternation Special Edition No 16: 19 - 43. Available at: http://alternation.ukzn.ac.za/Files/docs/22\%20SpEd16/02\%20Gachago\% 20F.pdf

Garneau, D. 2013. Extra-Rational Aesthetic Action and Cultural Decolonisation. FUSE Magazine 36,4.

See https://e-artexte.ca/id/eprint/25209/1/FUSE 36-4.pdf

Gaztambide-Fernández, R. 2014. Decolonial Options and Artisti/aestheSic engtanglements: An Interview with Walter Mignolo. Decolonization, Education \& Society 3,1: 196 - 212.

Haraway, D. 1988. Situated Knowledges: The Science Question in Feminism and the Privilege of Partial Perspective. Feminist Studies 14, 3: 575. https://doi.org/10.2307/3178066

Haraway, D. 2000. How Like a Leaf. An Interview with Thyrza Nichols Goodevel Donna J. Haraway. New York; London : Routledge.

Haraway, D. 2016. Staying with the Trouble: Making Kin in the Cthulucene. Durham \& London: Duke University Press. https://doi.org/10.1215/9780822373780

Kaiser, B. \& K. Thiele 2018. If You Do Well, Carry! The Difference of the Humane - An Interview with Bracha L. Ettinger. philoSOPHIA 8, 4: 10 125. https://doi.org/10.1353/phi.2018.0005

Leibowitz, B. \& V. Bozalek. 2015. Foundation Provision - A Social Justice Perspective. South African Journal of Higher Education 29,1: 8 - 25. https://doi.org/10.20853/29-1-447

Manning, E. 2016. The Minor Gesture. Duke University Press. https://doi.org/10.1215/9780822374411 
Matenga, E. 2011. The Soapstone Birds of Great Zimbabwe - Archaeological Heritage, Religion and Politics in Postcolonial Zimbabwe and the Return of Cultural Property. Uppsala: Uppsala University.

Matroos, J. 2018. Sethembile Msezane on Why she Uses her Art as Resistance. Available at: $\quad$ http://www.designindaba.com/articles/creativework/sethembile-msezane-why-she-uses-her-art-resistance

Nkoane, M.N. 2006. The Africanisation of the University in Africa. Alternation 13,1: 49 - 69.

Ndlovu-Gatsheni, S.J. 2016. Decolonizing the University and the Problematic Grammars of Change in South Africa. Keynote address, $5^{\text {th }}$ Annual Students' Conference on Decolonizing the Humanities and Social Sciences in South Africa/Africa, UKZN, 6-7 October 2016.

Pollock, G. 2010. Aesthetic Wit(h)nessing in the Era of Trauma. EurAmerica 40,4: 829 - 886.

Roth, W-M. 2014. Curriculum-in-the-making: A Post Constructive Perspective. New York: Peter Lang.

Sellers, M. 2013. Young Children becoming Curriculum: Deleuze, Te Whariki and Curricula Understandings. London \& New York: Routledge. https://doi.org/10.4324/9780203111819

Thiele, K. 2014. Ethos of Diffraction: New Paradigms for a (Post)humanist Ethics. Parallax 20,3: 202 - 216.

https://doi.org/10.1080/13534645.2014.927627

Zembylas, M. 2006. Witnessing in the Classroom: The Ethics and Politics of Affect. Educational Theory 56,3: 305 - 324. https://doi.org/10.1111/j.1741-5446.2006.00228.x

Nike Romano

Design Extended Curriculum Programme Cape Peninsula University of Technology niker@icon.co.za 